\title{
Assessment of Genetic Variability and Character Association for Yield and Its Contributing Components in Mid Maturing Indian Cauliflower
}

\author{
B. Vanlalneihi ${ }^{*}$, Partha Saha $^{2}$ and Mohita Srivastava ${ }^{2}$ \\ ${ }^{1}$ Division of Vegetable Science, Indian Institute of Horticultural Research \\ (IIHR), Bangalore, Karnataka, India \\ ${ }^{2}$ Divison of Vegetable Science, Indian Agricultural Research Institute (IARI), \\ New Delhi-12, India \\ *Corresponding author
}

\section{A B S T R A C T}

\begin{tabular}{|l|}
\hline K e y w o r d s \\
Mid maturing \\
cauliflower, Genetic \\
variability, \\
Correlation, Path \\
coefficient analysis.
\end{tabular}

Keywords

Mid maturing

cauliflower, Genetic

coefficient analysis.

\section{Introduction}

Cauliflower (Brassica oleracea var. botrytis L.) is one of the most important brassica vegetable grown during winter season in India. It is a monogenomic species belonging to ' $\mathrm{C}$ ' genome and possessed the chromosome number $n=9$ (Thamburaj and Singh, 2001). This crop has specific climatic requirement for the economic part i.e., curd development in comparison with other brassicaceous vegetables. Often cauliflower gave severe negative response to unfavorable environmental conditions viz., extreme temperatures and droughts that lead to economic reduction as results of pre mature curd formation (Singh et al., 2014).
Exploration of the existence of genetic variability is pivotal for cauliflower crop improvement. Estimation of the existing genetic parameters serves as a basic tool for selection and hybridization since the degree of variability for a given character is pre requisite for its improvement.

Hence, considering the complexity of quantitative inheritance pattern of various characters, the present investigation was formulated with an objective of assessing and quantifying the genetic variability, heritability coupled with genetic advance over percent of mean, correlation coefficient and path 
coefficient analysis for curd yield and its contributing traits.

\section{Materials and Methods}

The experimental materials for the present study consisted of 15 diverse accessions of cauliflower belonging to mid group collected from various parts of India and maintained at the Division of Vegetable Science, Indian Agricultural Research Institute (IARI), New Delhi. All these 15 genotypes were transplanted in the field during autumn-winter season of 2015-16 for comparative evaluation on various quantitative attributes. Experiment was laid out in Randomized Complete Block Design (RCBD) with three replications. There were 20 plants in each plot of $6 \mathrm{~m}^{2}$ area with a spacing of $50 \mathrm{~cm}$ distance between and $45 \mathrm{~cm}$ within row and standard package of practices were followed to raise a good crop.

At fully developed vegetative stage, five samples were randomly selected for each genotype except for days to maturity which was recorded on replication basis. Leaf characteristics were recorded from the second whorl from the inner side. An observation was recorded for yield and other contributing characters. Phenotypic data were recorded as per the guidelines for the conduct of test for Distinctiveness, Uniformity and Stability of cauliflower (Brassica oleracea var. botrytis L.) namely, plant height $(\mathrm{cm})$, number of leaf per plant, leaf length $(\mathrm{cm})$, leaf width $(\mathrm{cm})$, days to $50 \%$ curd initiation, days to $50 \%$ curd maturity, curd angle $\left({ }^{\circ}\right)$, curd polar diameter $(\mathrm{cm})$, curd equatorial diameter $(\mathrm{cm})$, marketable curd weight $(\mathrm{kg})$, net curd weight $(\mathrm{kg})$ and curd yield (q/ha) (PPV \& FRA, 2001).

The average values were used for analysis of variance on the basis of Panse and Sukhatme (1954). Components of variance were computed and classified as per Burton and De Vane (1953) and Sivasubramaniam and
Madhava (1973), respectively. Broad sense heritability was computed as per Allard (1960) and genetic advance as percent of mean were calculated by following and Johnson et al., (1955). Correlation and path coefficient analysis were computed as per the formulation of Al-jibouri et al., (1958) Miller et al., (1958) and Dewey and Lu (1959), respectively.

\section{Results and Discussion}

The quantum of variability existing in the germplasm determined the success of breeding programmed (Kumar et al., 2011). The characters studied showed significant genotypic difference indicating the existence of ample genetic variability to be exploited in breeding programmed and was reflected in broad range observed for each trait (Table 1). The variation existing between phenotype and genotype coefficient depicted higher PCV over GCV indicating the influence of environment in the manifestation of these character and hence, direct selection for the improvement of this trait is not efficient.

This finding is in concordance with Singh $e t$ al., (2010), Kumar et al., (2011) and Dipti and Singh (2013) in cauliflower. However, a close proximity between the PCV and GCV indicates minor environmental interference. The traits such as leaf width $(\mathrm{cm})$, curd angle $\left({ }^{\circ}\right)$, curd polar diameter $(\mathrm{cm})$, marketable curd weight $(\mathrm{kg})$, net curd weight $(\mathrm{kg})$, and yield (q/ha) showed high PCV and GCV (Table 2).This result is in line with the conclusion of Santhosha et al., (2015) and in close harmony with Manaware et al., (2017). The advancement of such characters can be brought about by subjecting the progenies to vigorous environmental condition. Characters like days to $50 \%$ of curd initiation and days to $50 \%$ of curd maturity exhibited low phenotypic and genotypic variation which is in consonance with results reported by Akshay and Singh (2015) and Sahu (2017). 
Heritability estimates in broad sense alone does not give clear indication for selection of traits since significant environment interaction is noted (Johnson et al., 1955). Hence, heritability values considered along with the predicted genetic gain increase the effectiveness of this parameter as a tool in selection program. In the present study, heritability was recorded high for most of the characters. Compartmenting the heritability into additive and non- additive gene action gave direction for execution of breeding programmed. High heritability coupled with high genetic advance as percent of mean (> $20 \%$ ) were observed in plant height, number of leaves per plant, leaf length, curd angle and marketable curd weight which is in agreement with Sahu (2017). The finding of Santhosha et $a l .$, (2015) is similar with respect to leaf width, curd diameter, net curd weight and yield. Kumar et al., (2011) and Nimkar and Korla (2011) also observed high heritability coupled with high genetic advance as percent of mean for net curd weight. High heritability with high genetic advance showed that the genotypic variance for those characters were probably due to high additive gene effect (Panse, 1957) indicating the exploitation of direct phenotypic selection. Similar to the findings of Santhosha et al., (2015), traits such $50 \%$ of curd initiation and $50 \%$ of curd maturity exhibit high heritability with low genetic advance as $\%$ of mean $(<10 \%)$ which revealed the predominance of non-additive gene action in the expression of these characters; hence, heterosis breeding could be exploited.

Table.1 Range and mean value for different characters of 15 genotypes of mid maturing Indian cauliflower

\begin{tabular}{|c|c|c|c|c|c|c|c|c|c|c|c|c|}
\hline Components & $\begin{array}{l}\text { Plant } \\
\text { Height } \\
(\mathrm{cm})\end{array}$ & $\begin{array}{l}\text { Number } \\
\text { of Leaves } \\
\text { per Plant }\end{array}$ & $\begin{array}{l}\text { Leaf } \\
\text { Length } \\
(\mathrm{cm})\end{array}$ & $\begin{array}{l}\text { Leaf } \\
\text { Width } \\
(\mathrm{cm})\end{array}$ & $\begin{array}{l}\text { Curd } \\
\text { Angle } \\
\left({ }^{\circ}\right)\end{array}$ & $\begin{array}{l}\text { Days to } \\
50 \% \\
\text { Curd } \\
\text { Initiation }\end{array}$ & $\begin{array}{l}\text { Days to } \\
\mathbf{5 0 \%} \\
\text { Curd } \\
\text { Maturity }\end{array}$ & $\begin{array}{l}\text { Curd } \\
\text { Polar } \\
\text { Diameter } \\
\text { (cm) }\end{array}$ & $\begin{array}{l}\text { Curd } \\
\text { Equatorial } \\
\text { Diameter } \\
\text { (cm) }\end{array}$ & $\begin{array}{l}\text { Marketable } \\
\text { Curd Wt. } \\
\text { (kg) }\end{array}$ & $\begin{array}{l}\text { Net } \\
\text { Curd } \\
\text { Wt. } \\
\text { (kg) }\end{array}$ & $\begin{array}{l}\text { Yield } \\
\text { (q/ ha) }\end{array}$ \\
\hline \multirow[t]{3}{*}{ Range } & 30.20 & 14.20 & 22.06 & 10.06 & 15.08 & 91.33 & 104.67 & 4.84 & 8.43 & 0.170 & 0.150 & 49.33 \\
\hline & to & to & to & to & to & to & to & to & to & to & to & to \\
\hline & 54.23 & 21.53 & 43.17 & 24.33 & 37.89 & 105.33 & 121.33 & 9.76 & 15.22 & 0.357 & 0.310 & 103.33 \\
\hline MSS & $112.10^{* *}$ & $10.66^{* *}$ & $109.72^{* *}$ & $37.35^{* *}$ & $90.76^{* * *}$ & $60.81^{* *}$ & $72.70^{* *}$ & $5.39^{* *}$ & $7.39^{* *}$ & $0.007^{* *}$ & $0.006^{* * *}$ & $624.53^{* *}$ \\
\hline Mean & 43.65 & 17.44 & 33.32 & 15.96 & 25.50 & 97.51 & 111.44 & 6.37 & 10.25 & 0.235 & 0.204 & 67.74 \\
\hline $\mathrm{CD}_{0.05}$ & 3.45 & 1.40 & 2.70 & 1.28 & 1.93 & 7.86 & 9.00 & 0.48 & 0.79 & 0.021 & 0.019 & 5.10 \\
\hline
\end{tabular}

MSS: Mean sum of squares; *, ** Significant at 5 and $1 \%$ level, respectively.

Table.2 Estimates of different genetic parameters with reference to yield and yield contributing characters in 15 mid maturing Indian cauliflower genotypes

\begin{tabular}{|c|c|c|c|c|c|}
\hline Characters & PCV (\%) & GCV (\%) & Broad-sense heritability (\%) & Genetic advance & Genetic Advance as\% of mean \\
\hline Plant Height $(\mathrm{cm})$ & 14.13 & 13.95 & 97.45 & 12.38 & 29.36 \\
\hline Number of Leaves /Plant & 10.96 & 10.73 & 95.77 & 03.77 & 21.63 \\
\hline Leaf Length $(\mathrm{cm})$ & 18.25 & 18.10 & 98.36 & 12.32 & 36.99 \\
\hline Leaf Width (cm) & 22.19 & 22.07 & 98.91 & 07.22 & 45.21 \\
\hline Curd Angle $\left({ }^{\circ}\right)$ & 21.64 & 21.53 & 98.99 & 11.26 & 44.13 \\
\hline Days to $50 \%$ of Curd Initiation & 04.99 & 04.42 & 78.66 & 07.88 & 08.08 \\
\hline Days to $50 \%$ of Curd Maturity & 04.80 & 04.21 & 76.93 & 08.48 & 07.61 \\
\hline Curd Polar Diameter (cm) & 21.12 & 21.01 & 99.00 & 02.74 & 43.07 \\
\hline Curd Equatorial Diameter $(\mathrm{cm})$ & 15.42 & 15.26 & 97.99 & 03.19 & 31.12 \\
\hline Marketable Curd Weight (kg) & 20.09 & 19.96 & 98.76 & 00.10 & 40.86 \\
\hline Net Curd Weight (kg) & 21.38 & 21.27 & 98.93 & 00.09 & 43.57 \\
\hline Yield (q/ ha) & 21.39 & 21.25 & 98.73 & 29.47 & 43.50 \\
\hline
\end{tabular}


Table.3 Phenotypic and genotypic correlation coefficients of different traits in mid maturing Indian cauliflower

\begin{tabular}{|c|c|c|c|c|c|c|c|c|c|c|c|c|}
\hline & & $\mathrm{X}_{1}$ & $\mathrm{X}_{2}$ & $X_{3}$ & $\mathrm{X}_{4}$ & $\mathrm{X}_{5}$ & $\mathrm{X}_{6}$ & $\mathrm{X}_{7}$ & $\mathrm{X}_{8}$ & $\mathrm{X}_{9}$ & $X_{10}$ & $X_{11}$ \\
\hline $\mathrm{X}_{2}$ & $\mathrm{P}$ & $-0.37^{*}$ & & & & & & & & & & \\
\hline \multirow[t]{2}{*}{$\mathrm{X}_{3}$} & 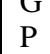 & $\begin{array}{l}-0.41 \\
0.90^{* * *}\end{array}$ & $-0.41^{* * *}$ & & & & & & & & & \\
\hline & G & $0.90^{* *}$ & $-0.44^{* *}$ & & & & & & & & & \\
\hline \multirow[t]{2}{*}{$\mathrm{X}_{4}$} & $P$ & $0.51^{* *}$ & $0.19^{\mathrm{NS}}$ & $0.44^{* *}$ & & & & & & & & \\
\hline & G & $0.51^{* * *}$ & $0.17^{\mathrm{NS}}$ & $0.43^{*}$ & & & & & & & & \\
\hline \multirow[t]{2}{*}{$X_{5}$} & $\mathrm{P}$ & $0.21^{\mathrm{NS}}$ & $0.13^{\mathrm{NS}}$ & $0.25^{\mathrm{NS}}$ & $0.25^{\mathrm{NS}}$ & & & & & & & \\
\hline & G & $0.20^{\mathrm{NS}}$ & $0.12^{\mathrm{NS}}$ & $0.24^{*}$ & $0.24^{\mathrm{NS}}$ & & & & & & & \\
\hline \multirow[t]{2}{*}{$X_{6}$} & $\mathrm{P}$ & $0.45^{* *}$ & $0.29^{\mathrm{NS}}$ & $0.56^{* *}$ & $0.46^{* *}$ & $0.48^{* *}$ & & & & & & \\
\hline & G & $0.43^{* * *}$ & 0.23 NS & $0.57^{*}$ & $0.46^{* *}$ & $0.49^{*}$ & & & & & & \\
\hline \multirow[t]{2}{*}{$X_{7}$} & $\mathrm{P}$ & $0.37^{*}$ & $0.27^{\mathrm{NS}}$ & $0.52^{* *}$ & $0.31^{*}$ & $0.38^{* *}$ & $0.97^{* *}$ & & & & & \\
\hline & G & $0.34^{*}$ & $0.20^{\mathrm{NS}}$ & $0.53^{*}$ & $0.30^{*}$ & $0.38^{*}$ & $0.96^{* *}$ & & & & & \\
\hline \multirow[t]{2}{*}{$\mathrm{X}_{8}$} & $\mathrm{P}$ & $0.45^{* *}$ & $0.12^{\mathrm{NS}}$ & $0.44^{* * *}$ & $0.40^{* *}$ & $0.29^{\mathrm{NS}}$ & $0.38^{* *}$ & $0.35^{*}$ & & & & \\
\hline & G & $0.45^{* *}$ & $0.11^{\mathrm{NS}}$ & $0.44^{* *}$ & $0.39^{* *}$ & $0.28^{\mathrm{NS}}$ & $0.38^{* *}$ & $0.35^{*}$ & & & & \\
\hline \multirow[t]{2}{*}{$\mathrm{X}_{9}$} & $P$ & $0.19^{\mathrm{NS}}$ & $0.06^{\mathrm{NS}}$ & $0.18^{\mathrm{NS}}$ & $0.13^{\mathrm{NS}}$ & $-0.11^{\mathrm{NS}}$ & $0.15^{\mathrm{NS}}$ & $0.18^{\mathrm{NS}}$ & $0.79^{* *}$ & & & \\
\hline & G & $0.18^{\mathrm{NS}}$ & $0.03^{\mathrm{NS}}$ & $0.17^{\mathrm{NS}}$ & $0.12^{\mathrm{NS}}$ & $-0.13^{\mathrm{NS}}$ & $0.10^{\mathrm{NS}}$ & $0.13^{\mathrm{NS}}$ & $0.79^{*}$ & & & \\
\hline \multirow[t]{2}{*}{$\mathrm{X}_{10}$} & $\mathrm{P}$ & $0.29^{\mathrm{NS}}$ & $0.10^{\mathrm{NS}}$ & $0.27^{\mathrm{NS}}$ & $0.24^{\mathrm{NS}}$ & $-0.25^{\mathrm{NS}}$ & $0.12^{\mathrm{NS}}$ & $0.13^{\mathrm{NS}}$ & $0.71^{* * *}$ & $0.87^{* *}$ & & \\
\hline & G & $0.28^{\mathrm{NS}}$ & $0.07^{\mathrm{NS}}$ & $0.26^{\mathrm{NS}}$ & $0.23^{\mathrm{NS}}$ & $-0.27^{\mathrm{NS}}$ & $0.07^{\mathrm{NS}}$ & $0.09^{\mathrm{NS}}$ & $0.71^{*}$ & $0.87^{* *}$ & & \\
\hline \multirow[t]{2}{*}{$X_{11}$} & $\mathrm{P}$ & $0.33^{*}$ & $0.09^{\mathrm{NS}}$ & $0.29^{\mathrm{NS}}$ & $0.28^{\mathrm{NS}}$ & $-0.27^{\mathrm{NS}}$ & $0.12^{\mathrm{NS}}$ & $0.11^{\mathrm{NS}}$ & $0.68^{* * *}$ & $0.83^{* *}$ & $0.98^{* *}$ & \\
\hline & G & $0.32^{*}$ & $0.07^{\mathrm{NS}}$ & $0.28^{\mathrm{NS}}$ & $0.28^{\mathrm{NS}}$ & $-0.28^{\mathrm{NS}}$ & $0.09^{\mathrm{NS}}$ & $0.07^{\mathrm{NS}}$ & $0.68^{*}$ & $0.83^{* *}$ & $0.98^{* *}$ & \\
\hline \multirow{2}{*}{$\mathrm{X}_{12}$} & $\mathrm{P}$ & $0.32^{*}$ & $0.07^{\mathrm{NS}}$ & $0.28^{\mathrm{NS}}$ & $0.27^{\mathrm{NS}}$ & $-0.28^{\mathrm{NS}}$ & $0.08^{\mathrm{NS}}$ & $0.06^{\mathrm{NS}}$ & $0.67^{* * *}$ & $0.82^{* *}$ & $0.97^{* *}$ & $0.99^{* *}$ \\
\hline & G & $0.33^{*}$ & $0.07^{\mathrm{NS}}$ & $0.28^{\mathrm{NS}}$ & $0.28^{\mathrm{NS}}$ & $-0.28^{\mathrm{NS}}$ & $0.11^{\mathrm{NS}}$ & $0.09^{\mathrm{NS}}$ & $0.68^{*}$ & $0.83^{* *}$ & $0.99^{* *}$ & $0.01^{* * *}$ \\
\hline
\end{tabular}

$*, * *$ Significant at $5 \%$ and $1 \%$ level, respectively.

$\mathrm{X}_{1}=$ Plant height $(\mathrm{cm})$;

$\mathrm{X}_{7}=$ Days to $50 \%$ of curd maturity;

$\mathrm{X}_{2}=$ Number of leaves per plant;

$\mathrm{X}_{8}=$ Curd polar diameter $(\mathrm{cm})$;

$\mathrm{X}_{3}=$ Leaf length $(\mathrm{cm})$

$\mathrm{X}_{9}=$ Curd equatorial diameter $(\mathrm{cm})$;

$\mathrm{X}_{4}=$ Leaf width $(\mathrm{cm})$;

$\mathrm{X}_{10}=$ Marketable curd weight $(\mathrm{kg})$;

$\mathrm{X}_{5}=$ Curd angle $\left({ }^{\circ}\right)$

$\mathrm{X}_{6}=$ Days to $50 \%$ of curd initiation;

$\mathrm{X}_{11}=$ Net curd weight $(\mathrm{kg})$;

$\mathrm{X}_{12}=$ Yield $(\mathrm{q} / \mathrm{ha})$.

Table.4 Estimates of direct (diagonal) and indirect effect at genotypic level for different characters on curd yield in 15 mid maturing Indian cauliflowers

\begin{tabular}{l|lllllllllll}
\hline & $\mathrm{X}_{1}$ & $\mathrm{X}_{2}$ & $\mathrm{X}_{3}$ & $\mathrm{X}_{4}$ & $\mathrm{X}_{5}$ & $\mathrm{X}_{6}$ & $\mathrm{X}_{7}$ & $\mathrm{X}_{8}$ & $\mathrm{X}_{9}$ & $\mathrm{X}_{10}$ & $\mathrm{X}_{11}$ \\
\hline $\mathrm{X}_{1}$ & $\mathbf{0 . 0 4 7}$ & -0.019 & 0.042 & 0.024 & 0.009 & 0.020 & 0.016 & 0.021 & 0.008 & 0.013 & 0.015 \\
$\mathrm{X}_{2}$ & 0.002 & $\mathbf{- 0 . 0 0 5}$ & 0.002 & -0.001 & -0.001 & -0.001 & -0.001 & -0.001 & -0.000 & -0.00 & -0.000 \\
$\mathrm{X}_{3}$ & -0.047 & 0.023 & $\mathbf{- 0 . 0 5 2}$ & -0.023 & -0.013 & -0.030 & -0.028 & -0.023 & -0.009 & -0.014 & -0.015 \\
$\mathrm{X}_{4}$ & -0.006 & -0.002 & -0.005 & $\mathbf{- 0 . 0 1 1}$ & -0.003 & -0.005 & -0.003 & -0.004 & -0.001 & -0.003 & -0.003 \\
$\mathrm{X}_{5}$ & -0.001 & -0.001 & -0.001 & -0.001 & $\mathbf{- 0 . 0 0 5}$ & -0.003 & -0.002 & -0.002 & 0.001 & 0.001 & 0.001 \\
$\mathrm{X}_{6}$ & 0.025 & 0.013 & 0.033 & 0.027 & 0.028 & $\mathbf{0 . 0 5 8}$ & 0.055 & 0.022 & 0.006 & 0.004 & 0.005 \\
$\mathrm{X}_{7}$ & -0.004 & -0.002 & -0.006 & -0.003 & -0.004 & -0.011 & $\mathbf{- 0 . 0 1 1}$ & -0.004 & -0.001 & -0.001 & -0.001 \\
$\mathrm{X}_{8}$ & -0.009 & -0.002 & -0.009 & -0.008 & -0.006 & -0.008 & -0.007 & $\mathbf{- 0 . 0 2 1}$ & -0.017 & -0.015 & -0.014 \\
$\mathrm{X}_{9}$ & 0.002 & 0.000 & 0.001 & 0.001 & -0.001 & 0.001 & 0.001 & 0.007 & $\mathbf{0 . 0 0 9}$ & 0.007 & 0.007 \\
$\mathrm{X}_{10}$ & 0.022 & 0.006 & 0.021 & 0.019 & -0.022 & 0.006 & 0.007 & 0.057 & 0.070 & $\mathbf{0 . 0 8 1}$ & 0.080 \\
$\mathrm{X}_{11}$ & 0.298 & 0.62 & 0.258 & 0.257 & -0.260 & 0.082 & 0.063 & 0.631 & 0.768 & 0.914 & $\mathbf{0 . 9 3 0}$ \\
\hline
\end{tabular}

Residual effect $=0.0108$

$\mathrm{X}_{1}=$ Plant height $(\mathrm{cm})$;

$\mathrm{X}_{2}=$ Number of leaves per plant;

$\mathrm{X}_{3}=$ Leaf length $(\mathrm{cm}) ;$

$\mathrm{X}_{4}=$ Leaf width $(\mathrm{cm})$;

$\mathrm{X}_{5}=$ Curd angle $\left(^{\circ}\right) ;$

$\mathrm{X}_{6}=$ Days to $50 \%$ of curd initiation;
$\mathrm{X}_{7}=$ Days to $50 \%$ of curd maturity;

$\mathrm{X}_{8}=$ Curd polar diameter $(\mathrm{cm})$;

$\mathrm{X}_{9}=$ Curd equatorial diameter $(\mathrm{cm})$;

$\mathrm{X}_{10}=$ Marketable curd weight $(\mathrm{kg})$;

$X_{11}=$ Net curd weight $(\mathrm{kg})$;

$\mathrm{X}_{12}=$ Yield $(\mathrm{q} / \mathrm{ha})$. 
Correlation studies (Table 3) revealed the influence of environment on phenotypic expression regardless of the strong inherent association among these traits. In, the present investigation, a positive and significant association was recorded for the entire ancillary characters viz., plant height, curd polar diameter, curd equatorial diameter, marketable curd weight and net curd weight with curd yield. Similar observation was reported by Kumar et al., (2011); Singh et al., (2014b) and Santhosha et al., (2015). Curd polar and equatorial diameter has positive significant association with marketable curd weight and net curd weight at phenotypic and genotypic level. The result for curd equatorial diameter was in conformity with Kumar et al., (2017) but contrast with the current finding for curd polar diameter. Some characters do not produce significant correlation with yield which might be due to extreme negative effects. Correlation analysis depicts the association among the traits although it does not give direct effect on the magnitude and nature towards yield. Henceforth, path coefficient analysis at genotypic level (Table 4) was estimated to partition the direct and indirect effect of the twelve morphological traits on yield for efficient weightage and effective improvement of desirable traits.

Net curd weight had maximum direct positive contribution on curd yield which is in conformity with Kumar et al., (2011); Sheemar et al., (2012), Nimkar (2013), Singh et al., (2013) and Santhosha et al., (2015). The negative direct effects were recorded for number of leaves per plant, leaf length, leaf width, curd angle, curd maturity and curd polar diameter. Similar observations were recorded by Sahu (2017) for leaf length and leaf width, Singh et al., (2014b) for curd diameter, Singh et al., (2006) and Sheemar et al., (2012) for number of leaves per plant and for $50 \%$ of curd maturity, Kumar et al., (2011) reported similar finding. These results suggested the selection of lower values for particular traits. The value of the residual effect is low i.e., 0. 0108, this indicates the competency of the analysed characters in maximizing the curd yield. The present findings highlighted the existence of adequate genetic variability in the germplasm and the need to evaluate for economic traits improvement. The traits that showed positive correlation with yield and also exhibit direct or indirect effect on yield could bring improvement in yield and yield components.

\section{References}

Akshay, C. and Singh, D. K. 2015. Genetic variability studies in early cauliflower (Brassica oleracea var. botrytis L.). Electronic Journal of Plant Breeding. 6(3): 842-847.

Al-Jibouri, A.H., Miller, P.A. and Robinson, H.F. 1958. Genetic and environmental variances and covariance in upland cotton of inter-specific origin. Agronomy journal. 30: 633-37.

Allard, R.W. 1960. Principles of Plant Breeding. John Wiley \& Sons, Inc., New York, USA.

Burton, G. W. and Devane, E. H. 1953. Estimating heritability in tall fescue (Festuca arundinacea) from replicated clonal material. Agronomy Journal. 45(10): 478-481.

Dewey, D.R. and Lu, K.H. 1959. A correlation and path analysis of the components of crested wheat grass seed production. Agronomy journal. 51: 515518.

Dipti, M. and Singh, D. K. 2013. Studies on genetic variability for yield and its contributing attributes in early cauliflower (Brassica oleracea var. botrytis L.). Pantnagar Journal of Research. 11(2): 261-265.

Johnson, H. W., Robinson, H. F. and Comstock, R. E. 1955. Estimates of 
genetic environmental variability in soybeans. Agronomy journal.47(7): 314-318.

Kumar, M., Sharma, S. R., Kalia, P. and Saha, P. 2011. Genetic variability and character association for yield and quality traits in early maturing Indian cauliflowers. Indian Journal of Horticulture. 68(2): 206-211.

Kumar, V., Singh, D. K., Panchbhaiya, A. and Singh, N. 2017. Correlation and path coefficient analysis studies in midseason cauliflower (Brassica oleracea

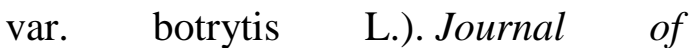
Pharmacognosy and Phytochemistry. 6(4): 1130-1137.

Manaware, D., Naidu, A. K. and Lal, N. 2017. Genetic diversity assessment for growth and tield Traits in cauliflower. International Journal of Current Microbiology and. Applied Science. 6(8): 3016-3027.

Miller, P.A, Williamm, C.V., Robinson, H.F. and Comstock, R.E. 1958. Estimates of genotypic and environmental variance and covariance in upland cotton and their implication in selection. Agronomy journal. 51:126-31.

Nimkar, S.A. 2013. Correlation and path coefficient studies in biparental progenies in cauliflower (Brassica oleracea var. botrytis L.). Research journal of Agricultural Science. 4(5/6): 667-669.

Nimkar, S.A. and Korla, B.N. 2011. Evaluation of biparental progenies developed through bud and mixed pollination for horticultural and quality traits in late cauliflower (Brassica oleracea var. botrytis L.). Indian Journal of Agricultural Research. 45(3): 215-20.

Panse, V. G. and Sukhatme, P. V. 1954. Statistical methods for agricultural workers. New Delhi: Indian Council of Agricultural Research Publications.
Panse, V.G. 1957. Genetics of quantitative characters in relation to plant breeding. Indian Journal of Genetics. 17:318-328

PPV and FRA.2001. Protection of Plant Varieties and Farmer's Right Act (No. 53 of 2001) Department of Agriculture and Cooperation, Ministry of Agriculture, Govt. of India, Krishi Bhavan, New Delhi.

Sahu, P. K. 2017. Studies on genetic variability and self-incompatibility in Indian cauliflower (Brassica oleracea (L.) var. botrytis), M.S. Thesis, Indira Gandhi Krishi Vishwavidyalaya, India.

Santhosha, H. M., Varalakshmi, B. and Manohar, R. K. 2015. Evaluation of early cauliflower (Brassica oleracea var. botrytis L.) germplasm under tropical conditions for various horticultural traits. The BioScan. 10(4): 1631-1635.

Sheemar, G., Singh, D., Malik, A. and Kumar, A. 2012. Correlation and path analysis studies of economic traits in cauliflower (Brassica oleracea var. botrytis L.). Journal of Agricultural Technology. 8(5): 1791-1799.

Singh, B., Chaubey, T., Jhan, A., Upadhyay, D. K. and Pandey, S. D. 2014. Morphological characterization of cauliflower varieties/cultivars using DUS Characters. SAARC Journal of Agriculture, 11(2): 183-191.PPV and FRA (2001). Protection of Plant Varieties and Farmer's Right Act (No. 53 of 2001) Department of Agriculture and Cooperation, Ministry of Agriculture, Govt. of India, Krishi Bhavan, New Delhi.

Singh, B., Mishra, A.K., Sanwal, S.K., Singh, P.K. and Rai, M. 2013. Genetic variability and character association analysis in cabbage hybrids. Indian Journal of Horticulture. 70(2): 296-299.

Singh, B., Pandey, A.K., Verma, A. and Rai, M. 2006. Genetic Variability in Aghani 
Group of Indian Cauliflower (Brassica oleracea var. botrytis L.). Indian Journal of Plant Genetic Resources. 19(1): 113-117.

Singh, G., Singh, D. K. and Bhardwaj, S. B. 2010. Variability studies in November maturity group of cauliflower (Brassica oleracea var. botrytis L.). Pantnagar Journal of Research. 8(2): 202-205.

Singh, K. P., Kamal Kant, Roy, R. K. and Jha, R. N. 2014b. Correlation and path co- efficient analysis in cauliflower (Brassica oleracea var. botrytis L.). International Journal of Agricultural Sciences. 10: 387-389.

Sivasubramanian, S. and Madhava Menon. 1973. Genotypic and phenotypic variability in rice. Madras Agricultural Journal. 60: 1093-1096.

Tamburaj, T. and Singh, N. 2001. Textbook of Vegetables, Tuber crops and Spices, ICAR (Pub.) New Delhi.

\section{How to cite this article:}

Vanlalneihi, B., Partha Saha and Mohita Srivastava. 2017. Assessment of Genetic Variability and Character Association for Yield and Its Contributing Components in Mid Maturing Indian Cauliflower. Int.J.Curr.Microbiol.App.Sci. 6(11): 2907-2913. doi: https://doi.org/10.20546/ijcmas.2017.611.343 